\title{
Article \\ A Comprehensive Investigation of the Structural, Thermal, and Biological Properties of Fully Randomized Biomedical Polyesters Synthesized with a Nontoxic Bismuth(III) Catalyst
}

\author{
Izabela M. Domańska ${ }^{1}$, Anna Zgadzaj ${ }^{2}$, Sebastian Kowalczyk ${ }^{3}{ }^{(D}$, Aldona Zalewska ${ }^{3}$, Ewa Oledzka ${ }^{1}$, \\ Krystyna Cieśla ${ }^{4}$, Andrzej Plichta ${ }^{3}(\mathbb{D})$ and Marcin Sobczak 1,5,*(D)
}

check for updates

Citation: Domańska, I.M.; Zgadzaj, A.; Kowalczyk, S.;

Zalewska, A.; Oledzka, E.; Cieśla, K.;

Plichta, A.; Sobczak, M. A

Comprehensive Investigation of the Structural, Thermal, and Biological Properties of Fully Randomized Biomedical Polyesters Synthesized with a Nontoxic Bismuth(III) Catalyst. Molecules 2022, 27, 1139. https:// doi.org/10.3390/molecules27031139

Academic Editors: Giuseppe Cirillo, Manuela Curcio and Orazio Vittorio

Received: 21 January 2022

Accepted: 4 February 2022

Published: 8 February 2022

Publisher's Note: MDPI stays neutral with regard to jurisdictional claims in published maps and institutional affiliations.

Copyright: (C) 2022 by the authors. Licensee MDPI, Basel, Switzerland. This article is an open access article distributed under the terms and conditions of the Creative Commons Attribution (CC BY) license (https:// creativecommons.org/licenses/by/ $4.0 /)$
1 Department of Biomaterials Chemistry, Chair of Analytical Chemistry and Biomaterials, Faculty of Pharmacy, Medical University of Warsaw, 1 Banacha Str., 02-097 Warsaw, Poland; izabela.domanska@wum.edu.pl (I.M.D.); ewa.oledzka@wum.edu.pl (E.O.)

2 Department of Environmental Health Sciences, Faculty of Pharmacy, Medical University of Warsaw, 1 Banacha Str., 02-097 Warsaw, Poland; anna.zgadzaj@wum.edu.pl

3 Faculty of Chemistry, Warsaw University of Technology, 3 Noakowskiego Str., 00-664 Warsaw, Poland skowalczyk@ch.pw.edu.pl (S.K.); aldona.zalewska@pw.edu.pl (A.Z.); andrzej.plichta@pw.edu.pl (A.P.)

4 Institute of Nuclear Chemistry and Technology, 16 Dorodna Str., 03-195 Warsaw, Poland; k.ciesla@ichtj.waw.pl

5 Military Institute of Hygiene and Epidemiology, 4 Kozielska Str., 01-163 Warsaw, Poland

* Correspondence: marcin.sobczak@wum.edu.pl; Tel.: +48-22-572-0783

\begin{abstract}
Aliphatic polyesters are the most common type of biodegradable synthetic polymer used in many pharmaceutical applications nowadays. This report describes the ring-opening polymerization (ROP) of L-lactide (L-LA), $\varepsilon$-caprolactone (CL) and glycolide (Gly) in the presence of a simple, inexpensive and convenient PEG200-BiOct 3 catalytic system. The chemical structures of the obtained copolymers were characterized by ${ }^{1} \mathrm{H}$ - or ${ }^{13} \mathrm{C}-\mathrm{NMR}$. GPC was used to estimate the average molecular weight of the resulting polyesters, whereas TGA and DSC were employed to determine the thermal properties of polymeric products. The effects of temperature, reaction time, and catalyst content on the polymerization process were investigated. Importantly, the obtained polyesters were not cyto- or genotoxic, which is significant in terms of the potential for medical applications (e.g., for drug delivery systems). As a result of transesterification, the copolymers obtained had a random distribution of comonomer units along the polymer chain. The thermal analysis indicated an amorphous nature of poly(L-lactide-co- $\varepsilon$-caprolactone) (PLACL) and a low degree of crystallinity of poly $\left(\varepsilon\right.$-caprolactone-co-glycolide) (PCLGA, $X_{\mathrm{C}}=15.1 \%$ ), in accordance with the microstructures with random distributions and short sequences of comonomer units $(l=1.02-2.82)$. Significant differences in reactivity were observed among comonomers, confirming preferential ring opening of L-LA during the copolymerization process.
\end{abstract}

Keywords: biodegradable polymers; aliphatic polyesters; poly( $\varepsilon$-caprolactone); poly(L-lactide);

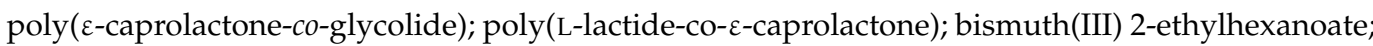
ring opening polymerization

\section{Introduction}

Bio-based polymeric materials are widely used in medicine and pharmacy (e.g., tissue engineering, drug delivery systems (DDSs), etc.). The most desirable are drug carriers derived from biocompatible polyesters, of which homo- and copolymers containing $\varepsilon$-oxycaproyl (Cap), glycolidyl (GG) and lactidyl (LL) units are the most commonly used biomaterials [1,2]. Concomitantly, the advantage of polyester drug carriers is their biodegradability. These polymers, once introduced into the organism, are well tolerated, metabolically decomposed, and eliminated via normal metabolic pathways [1]. The most attractive catalytic systems for the synthesis of polyesters are those consisting of metals 
(Zn, Sn, Zr, Fe). Nevertheless, the resulted polymers may contain traces of metal pollutants, leading to their high toxicity, which is undesirable for biomedical application [3]. As a result, they have been studied extensively over the last few decades, and significant progress has been made in terms of their synthesis using well-defined metalloorganic catalysts [4]. Among these, the use of alternative green catalysts has received particular consideration. Ring-opening polymerization (ROP) of lactones, such as L-lactide (L-LA), rac-lactide (rac-LA), $\varepsilon$-caprolactone ( $\mathrm{CL}$ ), and glycolide (Gly), using tin compounds as catalysts (e.g., tin(II) 2-ethylhexanoate $\left.\left(\mathrm{SnOct}_{2}\right)\right)$, is one of the methods of producing polyesters applied in medicine and pharmacy. Although the Food and Drug Administration (FDA) has approved $\mathrm{SnOct}_{2}$ as a food additive, tin(II) and tin(IV) ions or compounds tend to bind to the SH groups of proteins. In view of this, the catalyst is cytotoxic to some extent [5], and, thus, the resulting polymers should not be considered fully biocompatible [1]. Among other catalysts considered as non-toxic are $\mathrm{Zn}$ - and $\mathrm{Zr}$ - based compounds [3]. Our previous studies have shown that the polymers synthesized in the presence of diethylzinc [3] and zirconium(IV) acetylacetonate [6] may be considered as non-toxic in terms of cyto- and genotoxicity and thereby be suitable for pharmaceutical and medical applications.

Given the foregoing, in this work we will concentrate on bismuth(III) 2-ethylhexanoate (bismuth octoate, $\mathrm{BiOct}_{3}$ ), a potential nontoxic organometallic catalyst. $\mathrm{Bi}(\mathrm{III})$ is one of the ultratrace elements and its salts have long been used in medicine as both externally and internally administered drugs $[4,7,8]$. For example, bismuth(III) subsalicylate (BiSS) is a commercial drug for travelers' diarrhea, nonulcer dyspepsia, and gastrointestinal complaints [7]. Furthermore, toxicity studies reveal that Bi(III) is not toxic even at the highest dose tested and it proved less toxic than $\mathrm{Zn}$ on cultured human kidney tubular cells [9]. According to Kowalik et al., bismuth-based complexes exhibit not only antimicrobial and anticancer activity, but recent results also reveal the ability to reduce some side effects of cisplatin in cancer therapy [10]. $\mathrm{Bi}(\mathrm{III})$ salts (such as $\mathrm{BiCl}_{3}, \mathrm{BiAc}_{3}, \mathrm{BiO}_{3}, \mathrm{Bi}$ (n-hexanoate) ${ }_{3}$ and BiSS) have previously been reported to act as catalysts in the copolymerization of CL, Gly, and L-LA in particular $[8,11]$. These compounds are stable in storage and, most importantly, nontoxic in the quantities needed [8]. Comparing to other nontoxic metal catalysts, bismuth (III) compounds are, therefore, well suited to ROP of lactides [4] and may lead to unusual, random Cap and LL sequences in the polymeric chain [11].

However, there are few reports of bismuth organometallic compounds being used as catalysts of the ROP of lactones. Kricheldorf and Serra [12] published the first reference using BiOct 3 . They highlighted its high effectivity and low tendency of racemization of lactides, even in high temperatures $\left(180^{\circ} \mathrm{C}\right)$ [12]. Though the synthesis of polyesters in the presence of BiOct $_{3}$ has already been published, the purpose of this study was to extend the prior research of Kricheldorf and Serra [12] towards the synthesis of the copolymers of cyclic carboxylic esters, with a potential use as drug carriers in oncology, as well as to evaluate the resulting polymers in relation to their thermal properties and microstructure. The microstructure of polymers influences the kinetics of biodegradation process [13] and is therefore important regarding drug release and, thus, pharmaceutical application.

In this paper, we describe the synthesis of CL, Gly, and L-LA homo- and copolymers in the presence of a biosafe bismuth(III) catalyst system. The structural, physicochemical, and biological properties of these biodegradable polymers were investigated. Low molar mass and dispersity characterize the developed products. Furthermore, they have a random distribution of comonomer units along the polymer chain, resulting in the polyesters being amorphous or having a low degree of crystallinity. Most importantly, the polymers formed are non-toxic. We hope that the polyesters produced can be used in DDSs technology.

\section{Materials and Methods}

\subsection{Materials}

L-Lactide (L-LA, (3S)-cis-3,6-Dimethyl-1,4-dioxane-2,5-dione, 98\%), $\varepsilon$-caprolactone (CL, 2-Oxepanone, $98 \%$ ) and poly(ethylene glycol) (PEG200, $\left.M_{n}=200 \mathrm{Da}\right)$ were purchased from Sigma-Aldrich Co. (Poznan, Poland). Glycolide (Gly, 1,4-Dioxane-2,5-dione, 98\%) was 
purchased from TCI Europe N.V. Co. (Zwijndrecht, Belgium) and bismuth 2-ethylhexanoate from Alfa Aesar Co., part of Thermo Fisher Scientific (Kandel, Germany). Methanol $\left(\mathrm{CH}_{3} \mathrm{OH}\right.$, analytical pure), chloroform $\left(\mathrm{CHCl}_{3}\right.$, analytical pure), dichloromethane (DCM, $\mathrm{CH}_{2} \mathrm{Cl}_{2}$, analytical pure) and hydrochloric acid ( $\mathrm{HCl}, 35-38 \%$ ) were obtained from $\mathrm{POCH}$ Co. (Gliwice, Poland).

\subsection{Synthesis of Homo- and Copolymers via ROP}

The polymeric materials were formed in bulk by the ROP of CL, Gly, and L-LA in the presence of a PEG200-BiOct 3 catalytic system. In brief, appropriate amounts of monomers and PEG200 (1 to $5 \mathrm{~g}$ in total) were placed in dry glass ampules (the initiator to monomer ratio was constant as 1:100). Under dry argon, the reaction tubes were degassed and the catalytic amounts of $\mathrm{BiOct}_{3}$ were charged. The reaction vessels were sealed and placed in a thermostated oil bath under various conditions, i.e., time and temperature. When the reaction was completed, the polymerization products were dissolved in DCM or chloroform and precipitated in a cold methanol solution containing $5 \%$ of $\mathrm{HCl}$ (twice) and a cold methanol (last precipitation). The procedure was carried out a total of three times. The isolated polymer was dried in a vacuum oven to a constant weight and stored at $4{ }^{\circ} \mathrm{C}$.

\subsection{Methods}

\subsubsection{Structural Analysis of Polymers}

Analyses of hydrogen nuclear magnetic resonance $\left({ }^{1} \mathrm{H}\right.$ NMR) and carbon-13 nuclear magnetic resonance $\left({ }^{13} \mathrm{C} \mathrm{NMR}\right)$ were carried out on an Agilent $400 \mathrm{MHz}$ spectrometer at room temperature using $\mathrm{CDCl}_{3}$ as a solvent. The spectra were collected using 32 scans $\left({ }^{1} \mathrm{H}\right.$ NMR) or 5000 scans $\left({ }^{13} \mathrm{C}\right.$ NMR) with a $1 \mathrm{~s}$ acquisition time.

The copolymer microstructure was characterized by means of the parameters calculated from ${ }^{1} \mathrm{H} \mathrm{NMR}$ and ${ }^{13} \mathrm{C}$ NMR spectra according to the equations presented in the literature: the average length of the lactidyl $\left(l_{\mathrm{LL}}^{\mathrm{e}}\right)$, glycolidyl $\left(l_{\mathrm{GG}}^{\mathrm{e}}\right)$ and caproyl $\left(l_{\mathrm{Cap}}^{\mathrm{e}}\right)$ blocks, randomization ratio $(R)$, and transesterification of the second mode $\left(T_{\mathrm{II}}\right)$ [14-17].

The monomer conversion $\left(c o n v_{\mathrm{i}}\right)$ was calculated using ${ }^{1} \mathrm{H}$ NMR by comparing integrated signals of equivalent protons from the monomer and the polymer, as follows:

$$
\operatorname{conv}_{\mathrm{i}}=\frac{I_{\mathrm{i}}}{I_{\mathrm{i}}+I_{\mathrm{I}}}
$$

where $I_{\mathrm{i}}$ and $I_{\mathrm{I}}$ are the integral intensities of signals from equivalent protons in the monomer and polymer, respectively.

The microstructures of the obtained copolymers were examined using ${ }^{1} \mathrm{H}$ NMR for PCLGA and ${ }^{13} \mathrm{C}$ NMR for PLACL in the most convenient spectrum ranges, namely the methylene proton region of GG units and the $\varepsilon$-methylene proton region of Cap units (PCLGA), as well as the carbonyl carbon range of Cap and LL units (PLACL). By analogy with the literature [14-17], spectral lines were assigned to corresponding comonomeric sequences.

${ }^{1} \mathrm{H}$ NMR and ${ }^{13} \mathrm{C}$ NMR spectra allow for the calculation of $l_{\mathrm{GG}}^{\mathrm{e}}$ and $l_{\mathrm{LL}}^{\mathrm{e}}$ using the Equation (2) and $l_{\text {Cap }}^{\mathrm{e}}$ using the Equation (3) for ${ }^{1} \mathrm{H}$ NMR spectrum and the Equation (4) for ${ }^{13} \mathrm{C}$ NMR spectrum, as well as the determination of the contribution of sequences formed as a result of a transesterification process [18].

$$
\begin{aligned}
& l_{\mathrm{XX}}^{\mathrm{e}}=\frac{1}{2} \times \frac{\mathrm{XXX}+\mathrm{XXCap}+\text { CapXX }+ \text { CapXCap }}{\text { CapXCap }+\frac{1}{2}(\mathrm{XXCap}+\text { CapXX })} \\
& l_{\text {Cap }}^{\mathrm{e}}=\frac{\text { CapCap }+ \text { XCap }}{\text { XCap }} \\
& l_{\text {Cap }}^{\mathrm{e}}=\frac{\text { XCapX }+ \text { CapCapX }+ \text { XCapCap }+ \text { CapCapCap }}{\text { XCapX }+\frac{1}{2}(\text { CapCapX }+ \text { XСapCap })}
\end{aligned}
$$


where $\mathrm{X}$ represents glycolyl unit $-\mathrm{OCH}_{2} \mathrm{CO}-(\mathrm{G})$ or lactyl unit $-\mathrm{OCH}\left(\mathrm{CH}_{3}\right) \mathrm{CO}-(\mathrm{L})$, Cap is caproil unit $-\mathrm{O}\left(\mathrm{CH}_{2}\right)_{5} \mathrm{CO}-$, and XCap, XXX, XXCap, and so forth are two- and three-element sequences in the polymer chain.

$T_{\text {II }}$ may cause scission of glycolidyl or lactidyl units in the copolymer chain leading to the formation of characteristic CapGCap or CapLCap sequences. The yield of $T_{\text {II }}$ is a quantitative determination of the second mode of transesterification process in the copolymer chain, and was calculated according to the Equation (5):

$$
T_{\text {II }}=\frac{[\text { CapXCap }]}{[\text { CapXCap }]_{R}}
$$

where [CapXCap] is the experimental concentration of CapXCap sequence and the [CapXCap] $]_{R}$ is the concentration of CapXCap sequence in a completely random chain.

The $[\text { CapXCap }]_{R}$ can be described by the following relation (Equation (6)) when the ratio of $[\mathrm{X}] /[\mathrm{Cap}]$ is denoted as $k^{\prime}$ :

$$
[\text { CapXCap }]_{\mathrm{R}}=\frac{k^{\prime 3}}{\left(k^{\prime}+1\right)^{3}}
$$

A degree of the randomness of the copolymer chain was calculated from the Equation (7):

$$
R=\frac{l_{X X}^{R}}{l_{X X}^{e}}
$$

where $l_{X X}^{R}$ and $l_{\text {Cap }}^{R}$ represent the average lengths of glycolidyl or lactidyl (Equation (8)) and caproyl blocks (Equation (9)), respectively, in a completely random copolymer chain.

$$
\begin{aligned}
& l_{\mathrm{XX}}^{\mathrm{R}}=\frac{k^{\prime}+1}{2 k^{\prime}} \\
& l_{\text {Cap }}^{\mathrm{R}}=k^{\prime}+1
\end{aligned}
$$

\subsubsection{Gel Permeation Chromatography}

The molar mass $\left(M_{n}\right)$ and molecular mass distribution $(\nexists)$ were determined by gel permeation chromatography (GPC) on a Viscotek system comprising GPCmax and TDA 305 (triple detection array (TDA): RI, IV, LS) equipped with DVB Jordi gel column(s) (linear, mixed bed) in DCM as an eluent at $30{ }^{\circ} \mathrm{C}$ at a flow rate of $1.0 \mathrm{~mL} \mathrm{~min}^{-1}$.

\subsubsection{Cyto- and Genotoxicity}

To assess the toxicity of polymeric materials, cytotoxicity and genotoxicity tests were carried out. In brief, the cytotoxicity of polymeric matrices was assessed using the neutral red uptake (NRU) test using BALB/c T3T clone A31 mice fibroblast cell line (American Type Culture Collection) in accordance with the International Organization for Standardization (ISO) 10993-5:2009 Annex A guideline [19]. The polymeric extracts for the assay were formed by incubating the sample in $1 \mathrm{mg} \mathrm{mL}^{-1}$ DMEM medium with $5 \%$ bovine serum for $24 \mathrm{~h}$ at $37^{\circ} \mathrm{C}$. Polyethylene film and latex were used as reference materials.

Genotoxicity of the polymeric materials was evaluated according to ISO 13829:2000 guideline [20] by the Umu-test with and without metabolic activation using Salmonella typhimurium TA3515/psk1002 (Deutsche Sammlung von Mikroorganismen und Zellkulturen $\mathrm{GmbH}$, Braunschweig, Germany). The polymeric samples were incubated in PBS buffer (GIBCO) for $24 \mathrm{~h}$ at $37^{\circ} \mathrm{C}$. The 2-aminoanthracene and 4-nitroquinoline $\mathrm{N}$-oxide were used as positive controls. 


\subsubsection{Thermal Properties}

Thermogravimetric analysis (TGA) was performed with a TGA Q500 V20.7 (TA Instruments) under nitrogen flow $\left(60 \mathrm{~mL} \mathrm{~min}^{-1}\right)$. The measurements were carried out at temperatures ranging from 35 to $600{ }^{\circ} \mathrm{C}$, with a heating rate of $10^{\circ} \mathrm{C} \mathrm{min}{ }^{-1}$ for the samples placed in an open platinum pan. In order to describe the process of thermal decomposition, the temperatures at which the sample lost $5 \%, 50 \%$, and $95 \%$ of mass $\left(T_{5 \%}, T_{50 \%}\right.$, and $T_{95 \%}$ respectively), as well as the final temperature of thermal decomposition $\left(T_{\mathrm{f}}\right)$, were presented. Additionally, the temperature of the maximum rate of thermal decomposition $\left(T_{\max }\right)$ was determined as the maximum of differential TGA (DTGA) curve. Furthermore, the mass loss of the sample, i.e., the mass loss as a result of evacuation of residual solvents and moisture at the temperature of $150{ }^{\circ} \mathrm{C}\left(\Delta m_{150}\right)$, and total mass loss of the sample at a temperature of $600{ }^{\circ} \mathrm{C}\left(\Delta m_{\mathrm{t}}\right)$, were calculated. $\Delta m_{\mathrm{t}}$ values were calculated in relation to the masses at $150^{\circ} \mathrm{C}$.

Differential scanning calorimetry (DSC) measurements were performed using a DSC Q200 instrument (TA Instruments) under nitrogen flow in the temperature range from -140 to $250{ }^{\circ} \mathrm{C}$ for the sample placed in aluminum pans, applying a heating rate of $10{ }^{\circ} \mathrm{C} \mathrm{min}-1$.

For the characterization of the melting and the cold crystallization processes, peak temperatures ( $T_{\mathrm{m}}$ and $T_{\mathrm{c}}$ respectively), onset temperatures $\left(T_{\mathrm{on}}\right)$, and melting and crystallization enthalpies $\left(\Delta H_{\mathrm{m}}\right.$ and $\Delta H_{\mathrm{c}}$, respectively) were determined. Based on the enthalpy values, the crystalline phase content (crystallinity, $X_{c}$ ) was calculated according to the following Equation (10):

$$
X_{\mathrm{c}}=\frac{\Delta H_{\mathrm{m}}-\Delta H_{\mathrm{c}}}{\sum_{\mathrm{i}}\left(W_{\mathrm{i}} \times \Delta H_{\mathrm{mi}, 100 \%}\right)}
$$

where $\Delta H_{\mathrm{m}}$ is enthalpy of melting, $\Delta H_{\mathrm{c}}$ is enthalpy of cold crystallization and $\Delta H_{\mathrm{mi}, 100 \%}$ is enthalpy of melting for a fully $(100 \%)$ crystalline homopolymer (literature data). The values of $106 \mathrm{~J} \mathrm{~g}^{-1}$ [21], $136 \mathrm{~J} \mathrm{~g}^{-1}$ [22] and $191 \mathrm{~J} \mathrm{~g}^{-1}$ [23] for $\Delta H_{\mathrm{m}, 100 \%}$ of PLA, PCL and polyglycolide were used respectively. $W_{\mathrm{i}}$ is the weight fraction of the Cap, LL and GG co-units in copolymers; for homopolymers, $W_{\mathrm{i}}=1$.

The glass transition temperature $\left(T_{\mathrm{g}}\right)$ was evaluated as its midpoint based on the first derivative of DSC curve (dDSC). The temperature value of the minimum of the effect generated on the dDSC curve was taken for this purpose [24]. Additionally, in order to estimate $T_{\mathrm{g}}$ of the copolymers, a simple Fox Equation (11) was used [25].

$$
\frac{1}{T_{\mathrm{g}}}=\frac{w_{1}}{T_{\mathrm{g} 1}}+\frac{w_{2}}{T_{\mathrm{g} 2}}
$$

where $T_{\mathrm{g}}$ is the glass transition of copolymers constructed from components 1 and 2 with weight fractions $w_{1}$ and $w_{2}$, respectively. $T_{\mathrm{g} 1}$ and $T_{\mathrm{g} 2}$ are the glass transitions of the individual homopolymers 1 and 2, respectively.

\section{Results and Discussion}

\subsection{Synthesis and Characterization of Polyesters}

Four different polymer matrices were synthesized via ROP of CL, Gly and L-LA in the presence of the simple, inexpensive and nontoxic PEG200-BiOct ${ }_{3}$ catalytic system. Bifunctional PEG200 was applied as a co-initiator, resulting in hydroxyl end-capped linear polyesters. The polymerization process was carried out at $110^{\circ} \mathrm{C}$ and $130^{\circ} \mathrm{C}$. The molar ratio of the monomers to the catalyst was 100:1. The number average molecular weight $\left(M_{n}\right)$ of synthesized polymers was controlled by the molar ratio of monomer to co-initiator, which was constant and equal to 100:1.

The ${ }^{1} \mathrm{H}$ NMR and ${ }^{13} \mathrm{C}$ NMR spectra of the synthesized polymers confirmed their structures. The polymers were obtained with a good monomer conversion (almost equilibrium conversion), acceptable yield and moderately narrow dispersities $(\Theta=1.23-2.59)$ (Table 1$)$. The theoretical $M_{n}$ of the polyesters was determined based on the original monomer and PEG200 content. However, the $M_{\mathrm{n}}$ values obtained by GPC were found to be different 
(lower in most cases) from the theoretical ones. The most probable reason is contamination of the sample with moisture, which results in hydrolysis of monomer to hydroxyl byproducts capable of initiating polymerization. As a result, polyesters with lower $M_{\mathrm{n}}$ fractions (Figure 1) were produced, leading to an increase in $Ð$ [26].

Another explanation for the discrepancy in the data might be a transesterification process that occurred during the polymer chain growth. As a consequence, bond cleavage occurs, creating a modification in the distribution of comonomeric units in the polymer chain [17].

Figure 2 depicts the kinetics of the polymerization process. After $24 \mathrm{~h}$, all monomers show complete conversion, verifying the mentioned earlier hypothesis that bismuth derivative catalysts are effective for ROP of cyclic esters. During the polymerization of PLACL, preferential ring opening towards lactide units was observed. L-LA conversion was almost quantitative after $5 \mathrm{~h}$, but CL conversion was substantially slower, reaching $76 \%$, $86 \%$, and $100 \%$ after $5 \mathrm{~h}, 7 \mathrm{~h}$, and $24 \mathrm{~h}$, respectively. A similar trend was observed for homopolymers (PLA vs PCL). PLA reached almost quantitative conversion of L-LA after $7 \mathrm{~h}$, compared to 93\% conversion of CL for PCL.
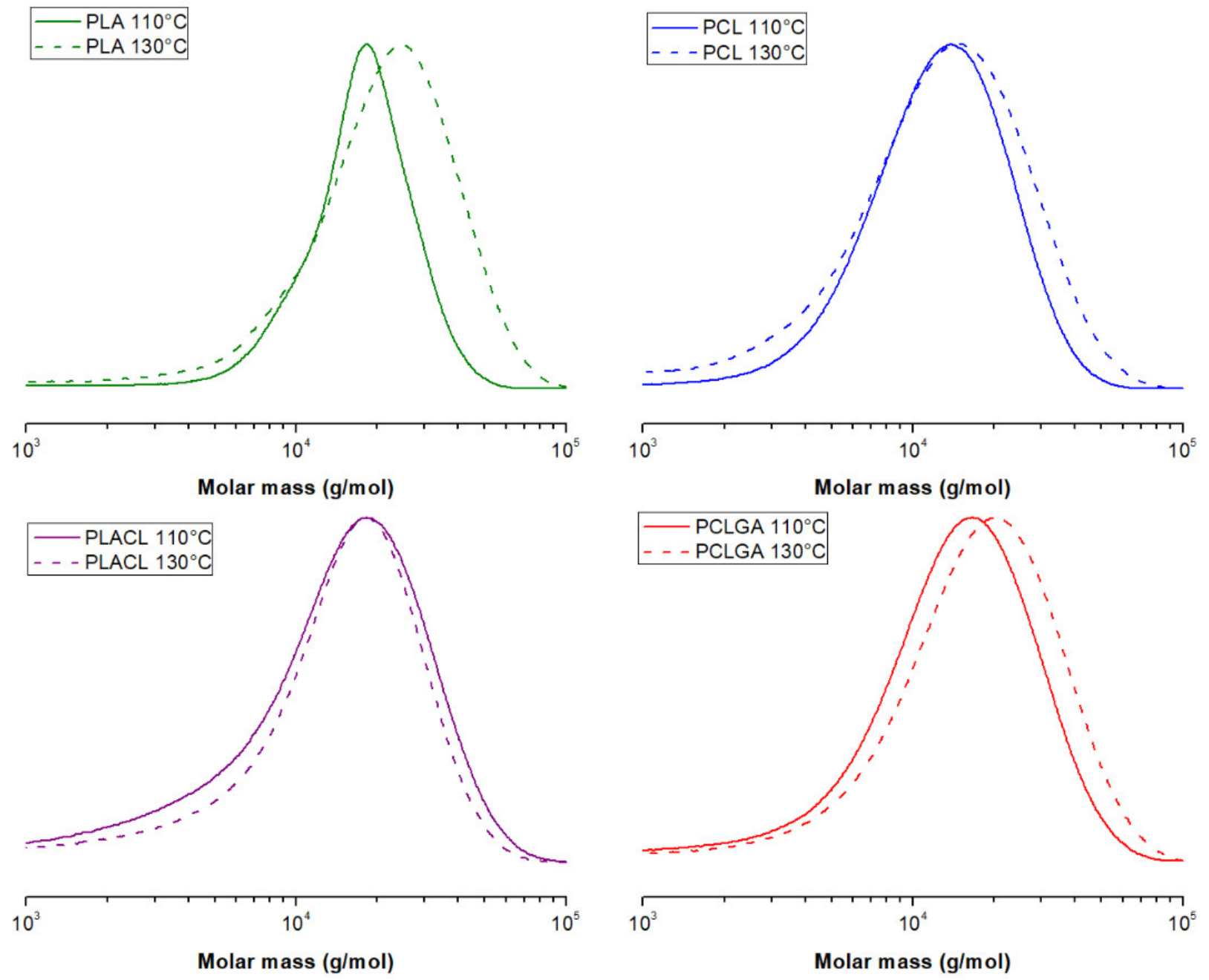

Figure 1. GPC traces for the polymers synthesized in $110{ }^{\circ} \mathrm{C}$ (solid line) vs. $130{ }^{\circ} \mathrm{C}$ (dashed line). 
Table 1. Homo- and copolymerization of CL, Gly and L-LA. Temperature-dependent optimization $(24$ h, PEG200:BiOct $3=1: 1)$.

\begin{tabular}{|c|c|c|c|c|c|c|c|}
\hline Sample & Molar Ratio & Temp. $\left({ }^{\circ} \mathrm{C}\right)$ & Yield (\%) & $\operatorname{Conv}_{\mathrm{i}}{ }^{\mathrm{a}}(\%)$ & $M_{\mathrm{n}}^{\mathrm{b}}(\mathrm{kDa})$ & $M_{\mathrm{n}}^{\mathrm{c}}(\mathrm{kDa})$ & $\oplus^{\mathrm{c}}$ \\
\hline \multirow{2}{*}{$\begin{array}{c}\text { PLA } \\
\text { poly(L-lactide) }\end{array}$} & $\mathrm{L}-\mathrm{LA}=1.0$ & 110 & 73 & 100 & 11.7 & 15.5 & 1.23 \\
\hline & L-LA $=1.0$ & 130 & 85 & 100 & 13.9 & 15.3 & 1.64 \\
\hline \multirow{2}{*}{$\begin{array}{c}\text { PCL } \\
\text { poly(e-caprolactone) }\end{array}$} & $C L=1.0$ & 110 & 50 & 94 & 11.4 & 8.8 & 1.67 \\
\hline & $\mathrm{CL}=1.0$ & 130 & 68 & 100 & 12.2 & 6.9 & 2.33 \\
\hline \multirow{2}{*}{ 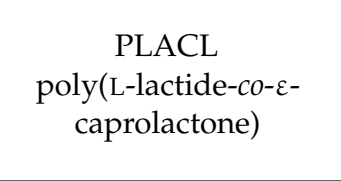 } & $\begin{array}{c}\mathrm{L}-\mathrm{LA}=0.45 \\
\mathrm{CL}=0.55\end{array}$ & 110 & 64 & $\begin{array}{l}99 \text { (L-LA) } \\
90(\mathrm{CL})\end{array}$ & 13.6 & 7.3 & 2.50 \\
\hline & $\begin{array}{c}\mathrm{L}-\mathrm{LA}=0.50 \\
\mathrm{CL}=0.50\end{array}$ & 130 & 56 & $\begin{array}{c}100(\mathrm{~L}-\mathrm{LA}) \\
100(\mathrm{CL})\end{array}$ & 10.2 & 9.7 & 1.87 \\
\hline \multirow{2}{*}{$\begin{array}{c}\text { CLGA } \\
\text { poly( } \varepsilon \text {-caprolactone-co- } \\
\text { glycolide })\end{array}$} & $\begin{array}{l}\mathrm{CL}=0.84 \\
\mathrm{GG}=0.16\end{array}$ & 110 & 60 & $\begin{array}{l}100 \text { (Gly) } \\
99 \text { (CL) }\end{array}$ & 11.5 & 6.8 & 2.59 \\
\hline & $\begin{aligned} \mathrm{CL} & =0.86 \\
\mathrm{GG} & =0.14\end{aligned}$ & 130 & 73 & $\begin{array}{l}100 \text { (Gly) } \\
100 \text { (CL) }\end{array}$ & 10.3 & 11.8 & 1.66 \\
\hline
\end{tabular}

a_calculated from ${ }^{1} \mathrm{H}$ NMR; ${ }^{\mathrm{b}}$ - calculated from the feed ratio ${ }^{\mathrm{c}}$ - determined from GPC.

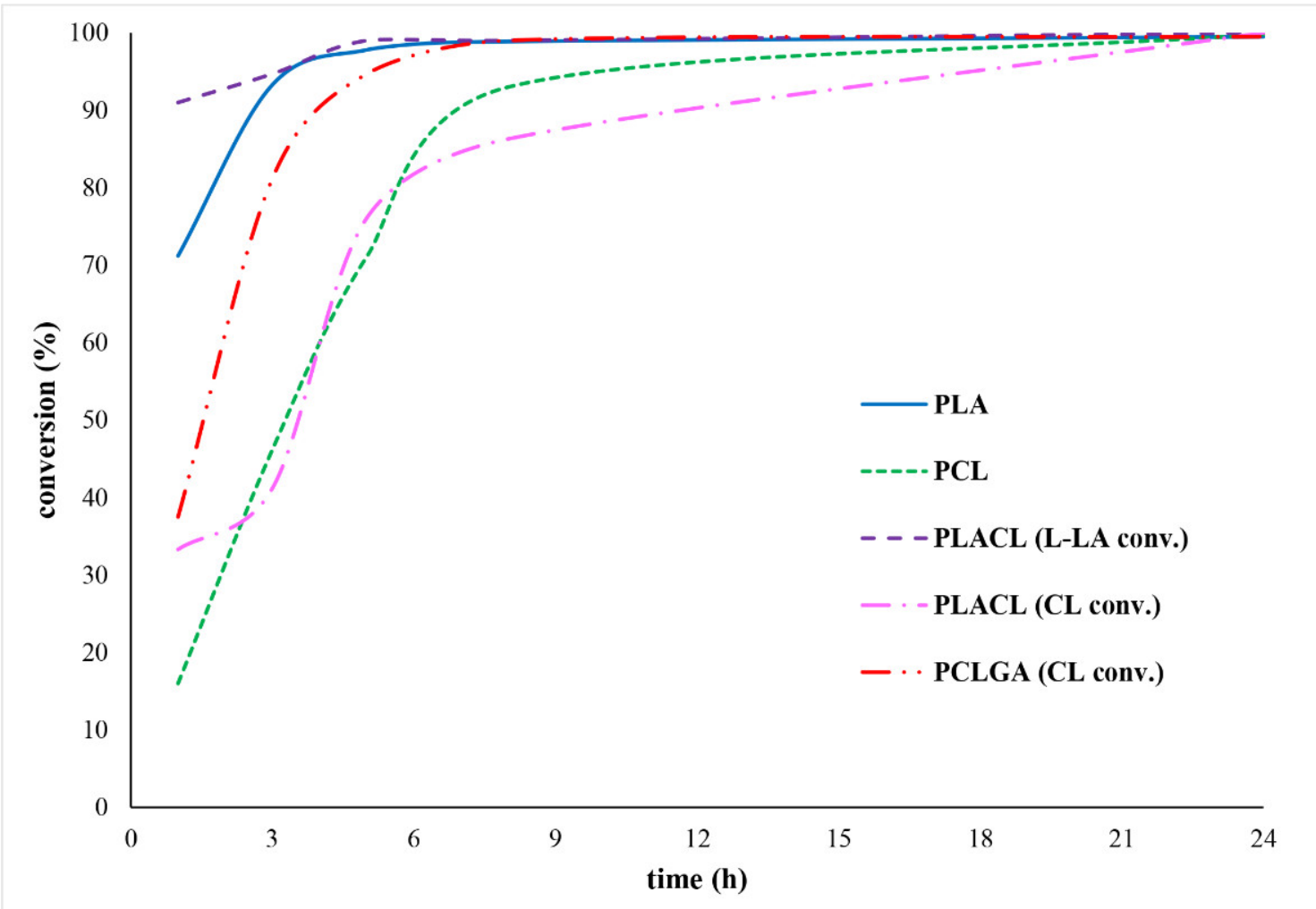

Figure 2. The polymerization kinetics of polymeric carriers $\left(130{ }^{\circ} \mathrm{C}\right.$, PEG200:BiOct $\left.3=1: 1\right)$.

The polymerization conditions were optimized in terms of time, temperature, and catalyst content, and were selected based on monomer conversion, yield, and $M_{\mathrm{n}}$ agreement with the theoretical value. The optimal polymerization conditions were set at $24 \mathrm{~h}$ and $130{ }^{\circ} \mathrm{C}$, with the exception of PLA, which had an optimum temperature of $110{ }^{\circ} \mathrm{C}$.

The polymerization process was then optimized for the lowest catalyst content while not influencing the properties of the formed polymer matrices (conversion degree, $M_{n}$, polydispersity index). Polymers were produced with a high yield and a monomer conversion close to 1 . The dispersity values ranged between 1.29 and 1.75 , of which the lowest value 
was observed for PLA. The $M_{\mathrm{n}}$ of the synthesized polymers was sufficiently consistent with the theoretically expected values (Table 2).

Table 2. Homo- and copolymerization of CL, Gly and L-LA. Catalyst content-dependent optimization $\left(24 \mathrm{~h}, 130{ }^{\circ} \mathrm{C}\left(110^{\circ} \mathrm{C}\right.\right.$ for PLA $)$, monomer:PEG200 = 100:1).

\begin{tabular}{|c|c|c|c|c|c|c|c|}
\hline Sample & $\begin{array}{c}\text { Monomer/ } \\
\text { Catalyst Molar Ratio }\end{array}$ & Molar Ratio & Yield (\%) & $\begin{array}{c}\operatorname{Conv}_{\mathrm{i}}{ }^{\mathrm{a}} \\
(\%)\end{array}$ & $\begin{array}{l}M_{\mathrm{n}}^{\mathrm{b}} \\
(\mathrm{kDa})\end{array}$ & $\begin{array}{l}M_{\mathrm{n}} \mathrm{c} \\
(\mathrm{kDa})\end{array}$ & $\bigoplus^{\mathrm{c}}$ \\
\hline PLA & 500 & $\mathrm{~L}-\mathrm{LA}=1.0$ & 90 & 98 & 12.1 & 12.3 & 1.29 \\
\hline PCL & 400 & $\mathrm{CL}=1.0$ & 70 & 100 & 11.7 & 10.8 & 1.59 \\
\hline PLACL & 300 & $\begin{array}{c}\mathrm{L}-\mathrm{LA}=0.52 \\
\mathrm{CL}=0.48\end{array}$ & 79 & $\begin{array}{l}99 \text { (L-LA) } \\
99(\mathrm{CL})\end{array}$ & 12.6 & 14.9 & 1.55 \\
\hline PCLGA & 1000 & $\begin{aligned} \mathrm{CL} & =0.85 \\
\mathrm{GG} & =0.15\end{aligned}$ & 78 & $\begin{array}{c}100 \text { (Gly) } \\
98 \text { (CL) }\end{array}$ & 11.8 & 10.4 & 1.75 \\
\hline
\end{tabular}

${ }^{\mathrm{a}}$-calculated from ${ }^{1} \mathrm{H}$ NMR; ${ }^{\mathrm{b}}$ - calculated from the feed ratio; ${ }^{\mathrm{c}}$ - determined from GPC.

TGA and DTGA curves are presented in Figure 3a,b. The characteristic values of temperature, where the samples reach particular decomposition steps of $5 \%, 50 \%$ and $95 \%\left(T_{5 \%}, T_{50 \%}\right.$ and $\left.T_{95 \%}\right)$, as well as $T_{\mathrm{f}}$ and $T_{\max }$, are summarized in Table 3 . Only small amounts of residues were observed at $600{ }^{\circ} \mathrm{C}$, suggesting complete thermal decomposition of polymers into volatile products.

(a)

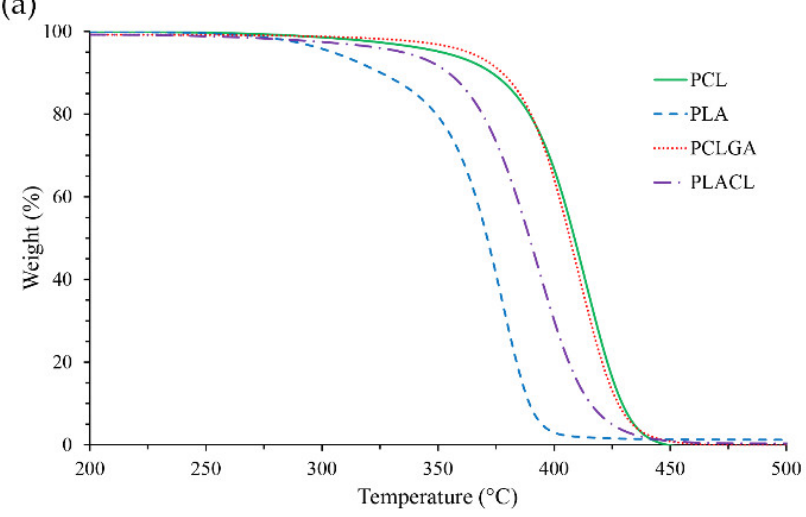

(b)

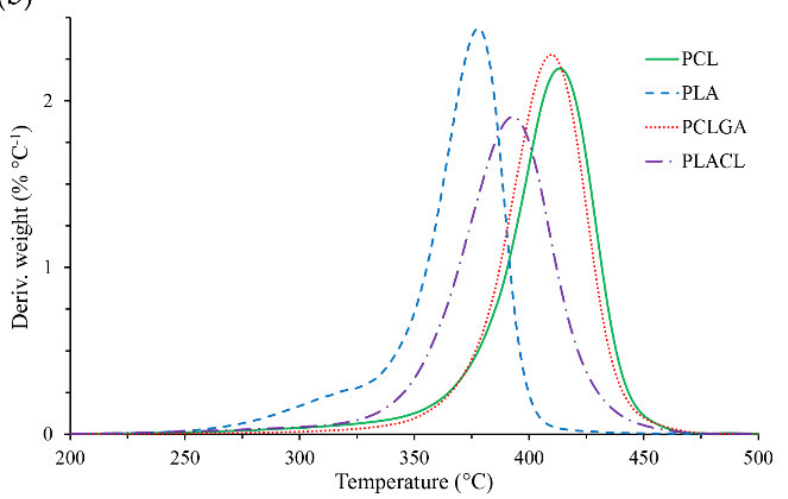

Figure 3. TGA (a) and DTGA (b) plots of the obtained polymeric carriers.

Table 3. Thermal decomposition of polymeric matrices.

\begin{tabular}{cccccccc}
\hline Sample & $\begin{array}{c}\Delta m_{\mathbf{1 5 0}} \\
\mathbf{( \% )}\end{array}$ & $\begin{array}{c}\Delta m_{\mathbf{t}} \\
\mathbf{( \% )}\end{array}$ & $\begin{array}{c}\boldsymbol{T}_{\mathbf{5}} \\
\left({ }^{\circ} \mathbf{C}\right)\end{array}$ & $\begin{array}{c}\boldsymbol{T}_{\mathbf{5 0}} \\
\left({ }^{\circ} \mathbf{C}\right)\end{array}$ & $\begin{array}{c}\boldsymbol{T}_{\mathbf{9 5 \%}} \\
\left({ }^{\circ} \mathbf{C}\right)\end{array}$ & $\begin{array}{c}\boldsymbol{T}_{\max } \\
\left({ }^{\circ} \mathbf{C}\right)\end{array}$ & $\begin{array}{c}\boldsymbol{T}_{\mathbf{f}} \\
\left({ }^{\circ} \mathbf{C}\right)\end{array}$ \\
\hline PLA & 0.02 & 98.77 & 304.5 & 371.2 & 394.6 & 377.9 & 414.9 \\
\hline PCL & 0.01 & 100.00 & 351.4 & 408.8 & 434.4 & 413.3 & 464.5 \\
\hline PLACL & 0.62 & 99.03 & 339.3 & 389.6 & 424.9 & 393.3 & 464.0 \\
\hline PCLGA & 0.58 & 99.50 & 365.4 & 406.9 & 433.8 & 409.8 \\
\hline
\end{tabular}

The data show the following sequence of thermal stability PCL $\geq$ PCLGA > PLACL > PLA. It was found that PLA was the least thermally stable polymer. However, the presence of Cap units in the copolymer chain significantly increased the thermal stability of PLACL, as shown by the shift of temperature of particular decomposition steps of thermal decomposition (compare PLACL and PLA, Table 3). For example, the shift of $T_{\max }$ value was equal to $15{ }^{\circ} \mathrm{C}$ in relation to PLA. To the contrary, only a small effect of GG units on thermal stability of PCLGA in relation to PCL was observed. In such cases, $T_{\max }$ shifted $3.5^{\circ} \mathrm{C}$ down. 
The curves display a one-step degradation in the case of PCL, PCLGA and PLACL (Figure $3 a, b)$. This confirms high homogeneity of both co-polymers, like the PCL homopolymer. However, in the case of PLA, a slight shoulder on DTGA curve (with max at ca. $320^{\circ} \mathrm{C}$, Figure $3 b$ ) was observed. This suggests the occurrence of an additional step of polymer decomposition. Despite very low dispersity of PLA $(\nexists=1.26)$, it can be supposed that in the first step (at low temperature), the fraction of the polymer characterized by the lower $M_{\mathrm{n}}$ (Figure 1) started to decompose.

Temperatures of glass transition $\left(T_{\mathrm{g}}\right)$, cold crystallization $\left(T_{\mathrm{c}}\right)$ and melting $\left(T_{\mathrm{m}}\right)$, as well as onset temperatures $\left(T_{\mathrm{on}}\right)$ of melting and crystallization, enthalpy of melting $\left(\Delta H_{\mathrm{m}}\right)$, enthalpy of cold crystallization $\left(\Delta H_{c}\right)$ and degree of crystallinity $\left(X_{c}\right)$, are listed in Table 4.

Table 4. Thermal parameters of polymeric matrices determined from DSC.

\begin{tabular}{|c|c|c|c|c|c|c|c|c|}
\hline Sample & $\begin{array}{c}T_{\mathrm{g}} \\
\left({ }^{\circ} \mathrm{C}\right)\end{array}$ & $\begin{array}{c}T_{\mathrm{c}} \\
\left({ }^{\circ} \mathrm{C}\right)\end{array}$ & $\begin{array}{c}T_{\text {on }}{ }^{a} \\
\left({ }^{\circ} \mathrm{C}\right)\end{array}$ & $\begin{array}{c}T_{\mathrm{m}} \\
\left({ }^{\circ} \mathrm{C}\right)\end{array}$ & $\begin{array}{c}T_{\text {on }} b \\
\left({ }^{\circ} \mathrm{C}\right)\end{array}$ & $\begin{array}{c}\Delta H_{\mathrm{c}} \\
\left(\mathrm{J} \mathrm{g}^{-1}\right)\end{array}$ & $\begin{array}{c}\Delta H_{\mathrm{m}} \\
\left(\mathrm{J} \mathrm{g}^{-1}\right)\end{array}$ & $\begin{array}{c}X_{\mathrm{c}} \\
(\%)\end{array}$ \\
\hline PLA & 54.4 & 104.6 & 102.1 & 158.9 & 156.9 & 15.5 & 51.4 & 33.9 \\
\hline PCL & -62.9 & nd & nd & 60.8 & 55.7 & nd & 128.5 & 98.1 \\
\hline PLACL & -12.3 & nd & nd & nd & nd & nd & nd & $0.0^{\mathrm{c}}$ \\
\hline PCLGA & -56.2 & -23.1 & -29.1 & $\begin{array}{l}20.0 \\
28.3\end{array}$ & 13.8 & 54.7 & 76.5 & 15.1 \\
\hline
\end{tabular}

a_cold crystallization process; ${ }^{\mathrm{b}}$ - -melting process; ${ }^{\mathrm{c}}$-amorphous; nd—not detected.

The distribution of the crystallites organization is an important factor influencing the processes. As seen in the DSC thermogram, upon heating of the PLA sample (Figure 4a) at temperature above glass transition, two processes are observed, i.e., crystallization (so called cold crystallization; exothermal effect), followed by melting (endothermal effect). The exothermal process may result from the release of energy due to rearranging of molecules into a lower energy configuration. This results in formation of the better organized (crystalline) phase $[27,28]$. The molten polymer is characterized by a higher energy compared to the crystalline phase. Due to the changes in the polymer energy states taking place at heating, energy is released or absorbed, which can be observed as exothermal or endothermal effects. Similarly, in the case of PCLGA, both crystallization and melting are observed at heating (Figure 4c). In comparison, only the melting endotherm was observed during heating of PCL (Figure $4 \mathrm{~b}$ ), which can be related to the high crystalline phase content determined for this polymer $\left(X_{\mathrm{C}}=98 \%\right)$. On the contrary, no effects of crystallization or melting are observed in the case of PLACL. This suggests an amorphous nature of the copolymer.

The single glass transition (Table 4) was observed in all cases, confirming good homogeneity of the obtained polymers. This process is clearly visible in the case of PLA (from $51.0^{\circ} \mathrm{C}$ to $56.4^{\circ} \mathrm{C}$ ), PLACL (from $-15.7^{\circ} \mathrm{C}$ to $-8.8^{\circ} \mathrm{C}$ ) and PCLGA (from -59.2 to $-54.4^{\circ} \mathrm{C}$ ), and very difficult for detection in the case of PCL (from $-63.1{ }^{\circ} \mathrm{C}$ to $-62.5^{\circ} \mathrm{C}$ ). Additionally, the values of $T_{\mathrm{g}}$, calculated from the Equation (11), for both copolymers PLACL $\left(-17.0^{\circ} \mathrm{C}\right)$ and PCLGA $\left(-52.4^{\circ} \mathrm{C}\right)$ are in good agreement with the measurements $\left(-12.3^{\circ} \mathrm{C}\right.$ and $-56.2^{\circ} \mathrm{C}$, respectively).

Thermal properties of all synthesized polymers are in close agreement with the literature data: PLA $\left(X_{\mathrm{c}}=35 \%\right.$ [29], $\left.T_{\mathrm{g}}=55-65^{\circ} \mathrm{C}, T_{\mathrm{m}}=145-183^{\circ} \mathrm{C}[30,31]\right) ; \mathrm{PCL}\left(T_{\mathrm{g}}=-60{ }^{\circ} \mathrm{C}\right.$, $T_{\mathrm{m}}=60{ }^{\circ} \mathrm{C}$ [32]; PLACL/50:50 $\left(T_{\mathrm{g}}=4{ }^{\circ} \mathrm{C}, T_{\mathrm{m}}=158^{\circ} \mathrm{C}\right.$ [33]); PCLGA of low Gly content $\left(T_{\mathrm{g}}=-60{ }^{\circ} \mathrm{C}, T_{\mathrm{m}}=54{ }^{\circ} \mathrm{C}[34,35]\right)$. It is known that molecular weight, monomer composition, and crystalline and rigid amorphous fractions development strictly affect thermal properties of polymers $[30,33,36]$. Therefore, some discrepancies in the results are probably due to chemical and structural differences in materials. 

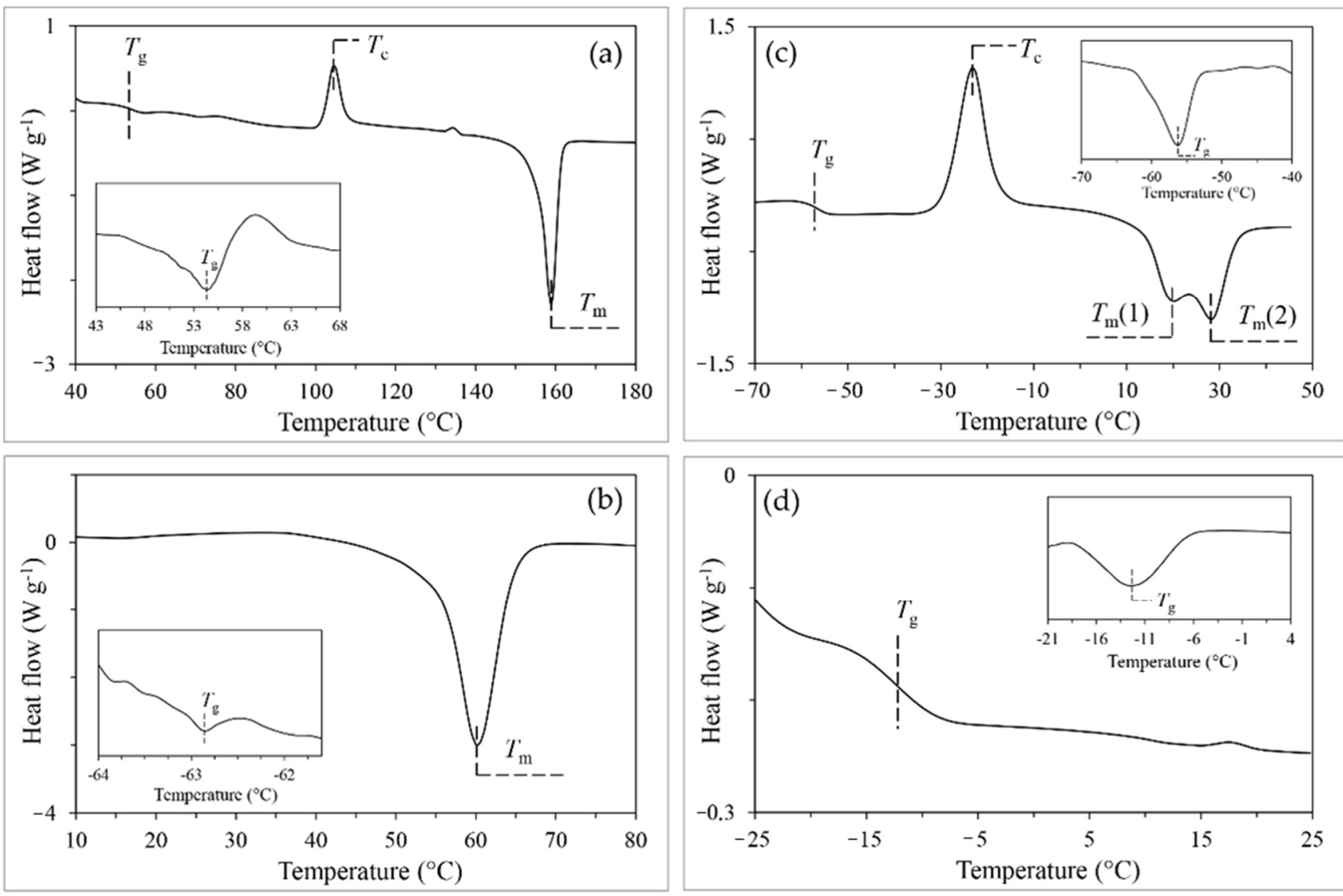

Figure 4. DSC thermograms of (a) PLA, (b) PCL, (c) PCLGA and (d) PLACL. DDSC curves in miniatures (determination of $T_{\mathrm{g}}$ ).

The differences between thermal properties of homo- and copolymers might be discussed in terms of the differences in composition and the reactions leading to their syntheses. Therefore, while PLA and PCL polymers are both crystalline (Figure $3 a, b)$, PLACL is amorphous (Figure 4d). The amorphous state of PLACL may be due to transesterification reactions occurring during the synthesis. Bond scissions in comonomeric units of the copolymer chain lead to shortening of LL and Cap block segments. As a result, the transesterification process increases the randomness of comonomer units along the chain and disrupts the crystallization process, hence reducing the size of crystallites. This conclusion corresponds to the results of D'Auria et al. [33], who analyzed random copolymers of LA and CL. The authors concluded that distribution of comonomers along the chain affects thermal behavior of the copolymer. The copolymers with low comonomer content $(\mathrm{LA}=0.1$ and $\mathrm{CL}=0.1)$ and long sequences of the prevailing comonomer unit $\left(l_{\text {Cap }}=12.2\right.$ and $l_{\mathrm{LL}}=11.1$ respectively) were crystalline, while the copolymer with LA content $(\mathrm{LA}=0.3)$ was amorphous, and only small amounts of crystalline phase were observed for the copolymers with the compositions $\mathrm{LA}=0.7$ and $\mathrm{LA}=0.5$, for which average lengths of comonomer sequences ( $l_{\mathrm{LL}}$ and $l_{\mathrm{Cap}}$ ) were in the range of 1.3-3.2.

In the case of the PCLGA, the melting endotherm with two minima in the temperature range of $10-40{ }^{\circ} \mathrm{C}$ was observed (Figure $4 \mathrm{c}$ ). This might be connected to the presence of two types of crystallites differing in size and/or morphology. Accordingly, small, poorly organized crystallites start melting at lower temperature, while the larger crystallites characterized by the better ordered structure melt at higher temperature. Among the others, this might result due to the possible presence of two different blocks in the copolymer chain: Cap units reach domain and GG units reach domain. However, this explanation seems insufficient considering the appearance of the single glass transition and the course of the thermal decomposition process showing rather good homogeneity of the material. Cold 
crystallization occurring during heating at low temperature might also lead to the formation of less perfect crystallites due to possible reorganization of the amorphous fraction, as well as the improvement of the structure of the crystallites resulting directly after synthesis. This may result in a diversification of the material, in which blocks of different organization will become present. However, the most likely hypothesis (remaining in substantial consent with the above), seems to be that in this temperature range, two processes (endothermal and exothermal) occur simultaneously, and the thermal effects of these processes overlap. Initially, the melting of the less crystallized fraction (endothermal) begins, followed by melt crystallization (exothermal). The new crystallites formed gradually in this way, with a higher degree of organization, melt at a higher temperature, which is still accompanied by an endothermal effect.

\subsection{Structural Characterization of the Synthesized Polyester Carriers}

As previously stated, the type of catalyst used and the transesterification process during synthesis have a strong influence on the microstructure of the polymers formed [1]. It was demonstrated that the structure of polymers may be controlled by modifying the kind of catalyst and the polymerization process parameters. Higher ROP process temperatures, for example, result in more random copolymers as a result of $T_{\mathrm{II}}$, which induces redistribution of comonomer units in the polymer chain [1].

The structure of homopolymers and the chain microstructure of copolymers were investigated using ${ }^{1} \mathrm{H}$ and ${ }^{13} \mathrm{C}$ NMR spectroscopy. The characteristic signals were assigned based on the literature $[14,16,37,38]$ and verified the structure of the obtained PCL, PLA, PLACL and PCLGA.

The ${ }^{1} \mathrm{H}$ NMR spectrum of the synthesized PCL: $4.22 \mathrm{ppm}\left(-\mathrm{O}-\left(\mathrm{CH}_{2}\right)_{5}-\mathrm{C}(\mathrm{O})-\mathrm{O}-\mathrm{CH}_{2}-\right.$ $\left.\mathrm{CH}_{2}-\mathrm{O}-\mathrm{CH}_{2}-\mathrm{CH}_{2}-\mathrm{O}-\right)$, 4.06 ppm (-O-C $\left.\mathrm{H}_{2}-\mathrm{CH}_{2}-\mathrm{CH}_{2}-\mathrm{CH}_{2}-\mathrm{CH}_{2}-\mathrm{C}(\mathrm{O})-\right)$, 3.69 ppm (-O- $\left(\mathrm{CH}_{2}\right)_{5}-$ $\left.\mathrm{C}(\mathrm{O})-\mathrm{O}-\mathrm{CH}_{2}-\mathrm{CH}_{2}-\mathrm{O}-\mathrm{CH}_{2}-\mathrm{CH}_{2}-\mathrm{O}-\right), 3.65 \mathrm{ppm}\left(\mathrm{HO}-\mathrm{CH}_{2}-\mathrm{CH}_{2}-\mathrm{CH}_{2}-\mathrm{CH}_{2}-\mathrm{CH}_{2}-\mathrm{C}(\mathrm{O})-\right)+(-\mathrm{O}-$ $\left.\left(\mathrm{CH}_{2}\right)_{2}-\mathrm{O}-\mathrm{CH}_{2}-\overline{\mathrm{CH}}_{2}-\mathrm{O}-\left(\mathrm{CH}_{2}\right)_{2}-\mathrm{O}-\right), 2.31$ ppm (-O-CH$\left.{ }_{2}-\mathrm{CH}_{2}-\mathrm{CH}_{2}-\mathrm{CH}_{2}-\mathrm{CH}_{2}-\mathrm{C}(\mathrm{O})-\right), 1.65$ ppm $\left(-\mathrm{O}-\mathrm{CH}_{2}-\mathrm{CH}_{2}-\mathrm{CH}_{2}-\mathrm{CH}_{2}-\mathrm{CH}_{2}-\mathrm{C}(\mathrm{O})-\right), 1.38 \mathrm{ppm}\left(-\mathrm{OC}-\mathrm{CH}_{2}-\mathrm{CH}_{2}-\mathrm{CH}_{2}-\mathrm{CH}_{2}-\mathrm{CH}_{2}-\mathrm{C}(\mathrm{O})-\right.$ ).

The ${ }^{1} \mathrm{H}$ NMR spectrum of the synthesized PLA: $5.17 \mathrm{ppm}\left(-\mathrm{O}(\mathrm{O}) \mathrm{C}-(\underline{\mathbf{H}}) \mathrm{C}\left(\mathrm{CH}_{3}\right)-\right)$, 4.36 ppm $\left(-\mathrm{O}(\mathrm{O}) \mathrm{C}-(\underline{\mathbf{H}}) \mathrm{C}\left(\mathrm{CH}_{3}\right)-\mathrm{OH}\right), 4.28 \mathrm{ppm}\left(-\mathrm{O}-\mathrm{CH}_{2}-\mathrm{CH}_{2}-\mathrm{O}(\mathrm{O}) \mathrm{C}-\left(\mathrm{CH}_{2}\right)_{5}-\mathrm{O}-\right), 3.68 \mathrm{ppm}$ $\left(-\mathrm{O}-\mathrm{CH}_{2}-\mathrm{CH}_{2}-\mathrm{O}(\mathrm{O}) \mathrm{C}-\left(\mathrm{CH}_{2}\right)_{5}-\mathrm{O}-\right), 3.62 \mathrm{ppm}\left(-\mathrm{O}-\left(\mathrm{CH}_{2}\right)_{2}-\mathrm{O}-\mathrm{CH}_{2}-\mathrm{CH}_{2}-\mathrm{O}-\left(\mathrm{CH}_{2}\right)_{2}-\mathrm{O}-\right), 1.59$ ppm $\left(-\mathrm{O}(\mathrm{O}) \mathrm{C}-(\mathrm{H}) \mathrm{C}\left(\mathrm{CH}_{3}\right)-\right)$.

The examination of the copolymers spectra, namely the ${ }^{1} \mathrm{H}$ NMR spectra of PCLGA $(C L: G l y=85: 15)$ (Figure 5) and the ${ }^{13}$ C NMR spectra of PLACL (CL:L-LA = 50:50) (Figure 6), allowed us to assign spectral lines to corresponding comonomeric sequences of PCLGA (Table 5) and PLACL (Table 6). Using the Equations (2)-(9) [14-16], the distribution of comonomeric units in the polymer chain was determined in accordance with the published data.

The copolymer of low monomer content $(\mathrm{Gly}=0.15$ and $\mathrm{CL}=0.85)$ characterized longer sequences of prevailing comonomer unit $\left(l_{\mathrm{Cap}}=2.82\right.$ and $\left.l_{\mathrm{G}}=1.02\right)$ and low crystallinity $\left(X_{\mathrm{C}}=15.1 \%\right)$, while PLACL $(\mathrm{L}-\mathrm{LA}=0.5$ and $\mathrm{CL}=0.5)$, having similar average lengths of comonomer sequences $\left(l_{\mathrm{L}}\right.$ and $\left.l_{\mathrm{Cap}}\right)$ of 2.80 and 1.41 respectively, was amorphous. The quantitative evaluation of their characteristic sequences (CapGCap and CapLCap) clearly demonstrates the effect of $T_{\mathrm{II}}$, which lead to unit redistribution in the examined copolymer chains (Table 7). High $T_{\mathrm{II}}$ value and random structure characterize the copolymers $(R=1.07$ for PLACL and $R=1.33$ for PCLGA). 


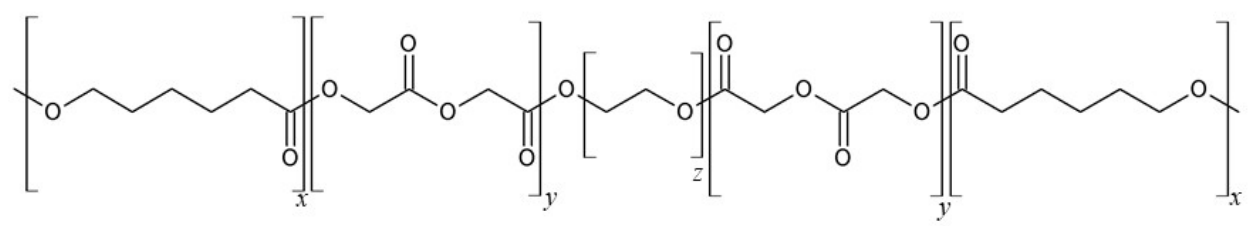

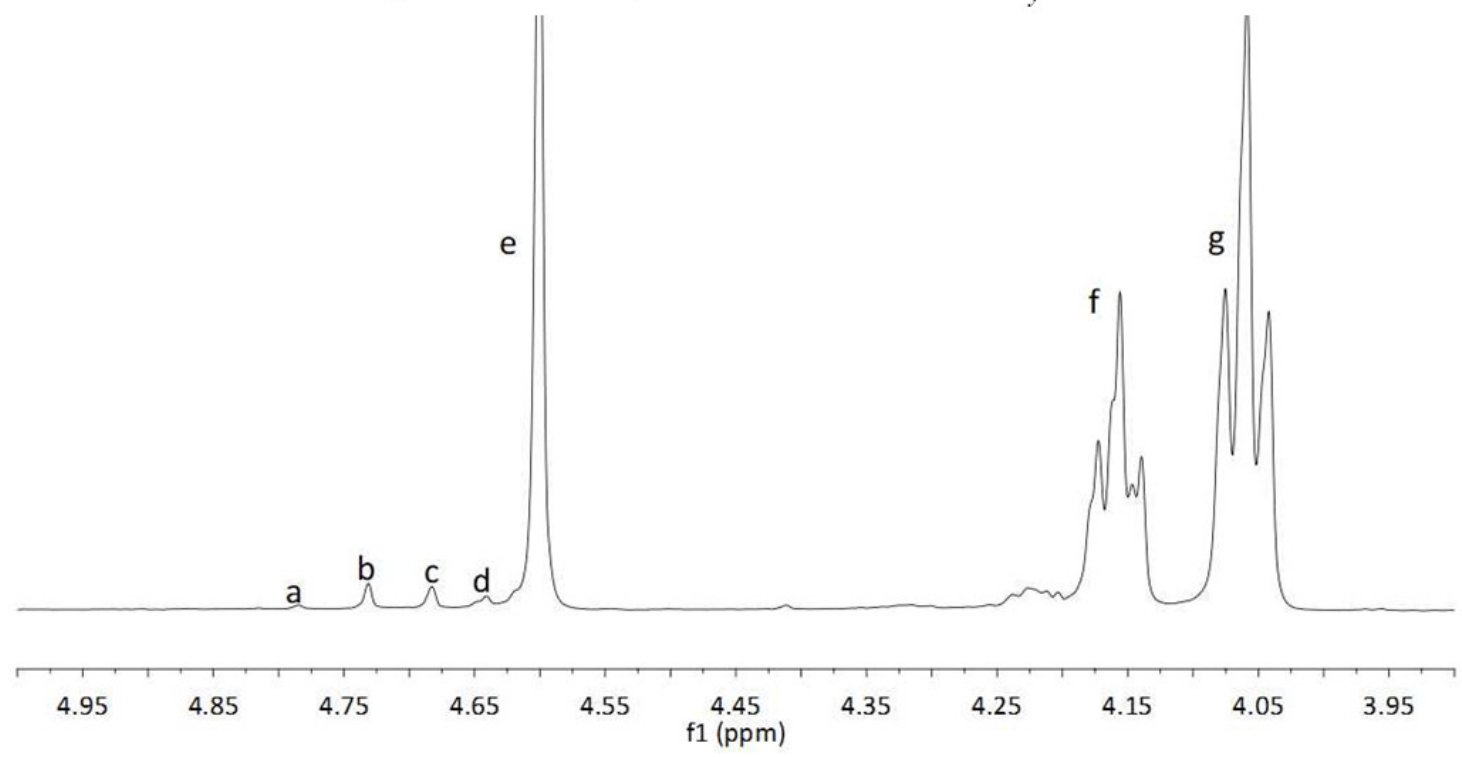

Figure 5. ${ }^{1} \mathrm{H}$ NMR spectrum of PCLGA.

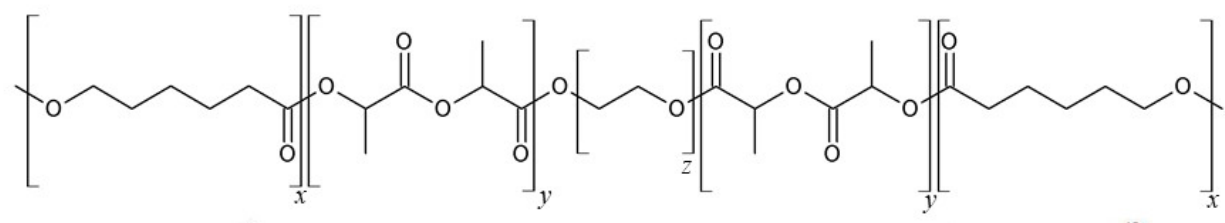

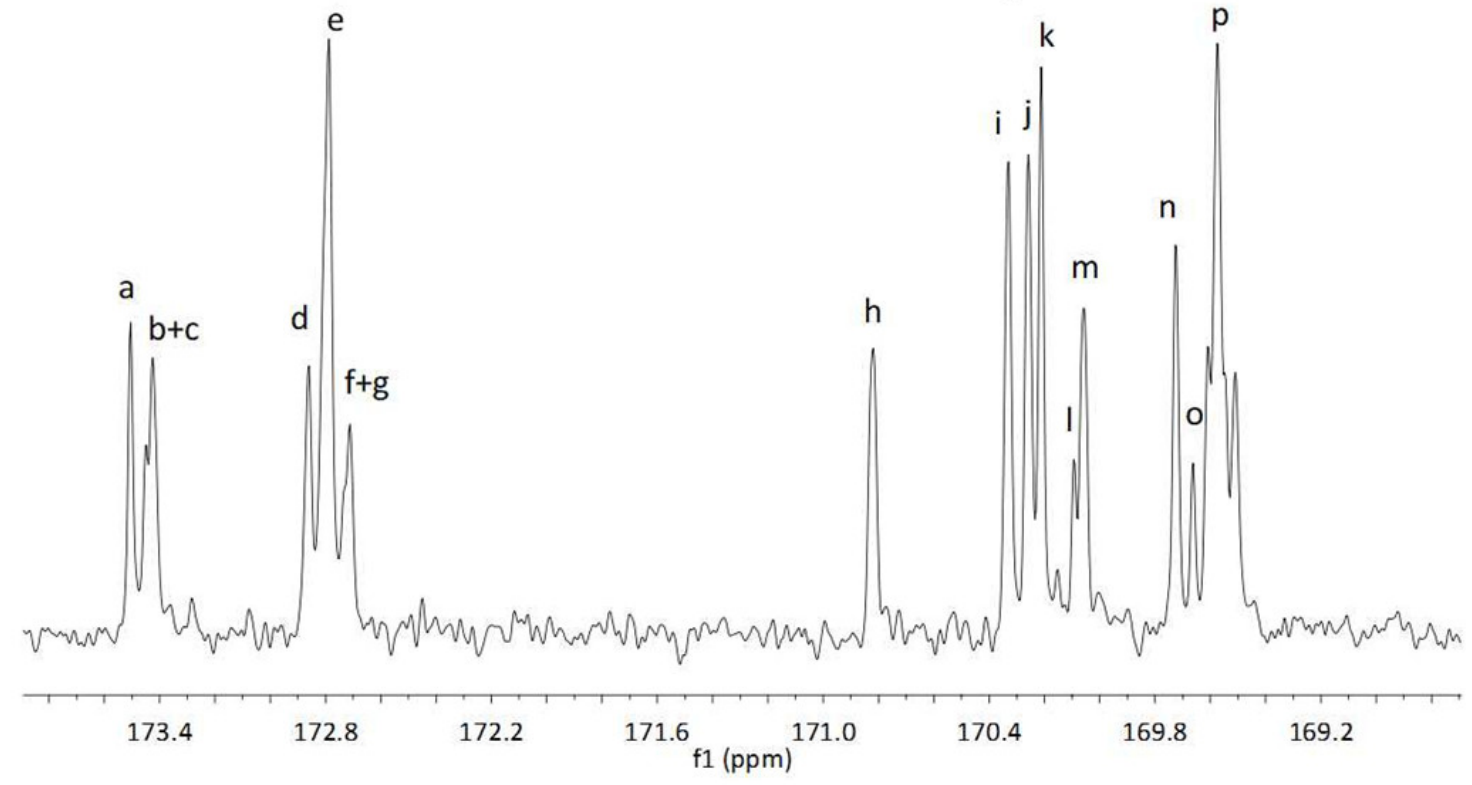

Figure 6. ${ }^{13} \mathrm{C}$ NMR spectrum of PLACL, region of carbonyl carbon atoms of $\varepsilon$-oxycaproyl and lactidyl units. 
Table 5. Chemical shifts in ${ }^{1} \mathrm{H}$ NMR spectrum of PCLGA.

\begin{tabular}{ccc}
\hline Signal & $\delta[\mathbf{p p m}]$ & Sequence \\
\hline $\mathrm{a}$ & 4.79 & G $\underline{\mathrm{G}} \mathrm{G}$ \\
\hline $\mathrm{b}$ & 4.73 & Cap $\underline{\mathrm{G}} \mathrm{G}$ \\
\hline $\mathrm{c}$ & 4.68 & G $\underline{\mathrm{G}}$ Cap \\
\hline $\mathrm{d}$ & 4.64 & Cap G G Cap \\
\hline $\mathrm{e}$ & 4.60 & Cap $\underline{\mathrm{G}}$ Cap \\
\hline $\mathrm{f}$ & 4.16 & G Cap \\
\hline $\mathrm{g}$ & 4.06 & Cap Cap \\
\hline
\end{tabular}

Table 6. Chemical shifts in ${ }^{13} \mathrm{C}$ NMR spectrum of PLACL, region of carbonyl carbon atoms of $\varepsilon$-oxycaproyl and lactidyl units.

\begin{tabular}{|c|c|c|}
\hline Signal & $\delta$ [ppm] & Sequence \\
\hline a & 173.59 & Cap Cap Cap \\
\hline $\mathrm{b}$ & 173.45 & Cap L Cap Cap \\
\hline c & 173.43 & L L Cap Cap \\
\hline $\mathrm{d}$ & 172.86 & Cap Cap L L \\
\hline e & 172.79 & L L Cap L L \\
\hline $\mathrm{f}$ & 172.73 & Cap L Cap L Cap \\
\hline$g$ & 172.71 & L L Cap L Cap \\
\hline $\mathrm{h}$ & 170.82 & Cap $\underline{\text { L Cap }}$ \\
\hline $\mathrm{i}$ & 170.33 & Cap L L $\underline{\mathbf{L}}$ Cap + L L L $\underline{\mathbf{L}}$ Cap \\
\hline $\mathrm{j}$ & 170.26 & Cap L $\underline{\mathbf{L}}$ Cap \\
\hline $\mathrm{k}$ & 170.21 & Cap L L Cap \\
\hline 1 & 170.09 & Cap L L L Cap \\
\hline $\mathrm{m}$ & 170.06 & Cap L L L L \\
\hline $\mathrm{n}$ & 160.73 & L L L L Cap \\
\hline o & 169.66 & Cap L $\underline{\text { L L Cap }}$ \\
\hline $\mathrm{p}$ & 169.57 & L L $\underline{\mathbf{L}} \mathrm{L} L+$ Cap L $\underline{\mathbf{L}} \mathrm{L} \mathrm{L}$ \\
\hline
\end{tabular}

Table 7. Structural characteristics of PLACL and PCLGA (synthesis parameters: $24 \mathrm{~h}, 130^{\circ} \mathrm{C}$ ).

\begin{tabular}{|c|c|c|c|}
\hline Kind of Copolymer/Molar Ratio & $\begin{array}{c}\text { The Average Length of } \\
\text { the Blocks }\end{array}$ & $T_{\mathrm{II}}$ & $R$ \\
\hline $\begin{array}{c}\text { poly(L-lactide-co- }- \text {-caprolactone) } \\
\text { PLACL/50:50 }\end{array}$ & $\begin{array}{c}l_{\mathrm{L}} \mathrm{e}^{\mathrm{e}}=2.80 \\
l_{\mathrm{CL}} \mathrm{e}^{\mathrm{a}}=1.41\end{array}$ & 0.70 & 1.07 \\
\hline $\begin{array}{c}\text { poly( } \varepsilon \text {-caprolactone-co-glycolide }) \\
\text { PCLGA/85:15 }\end{array}$ & $\begin{array}{l}l_{\mathrm{G}}^{\mathrm{e}}=1.02 \\
l_{\mathrm{CL}} \mathrm{e}^{\mathrm{e}}=2.82\end{array}$ & 0.96 & 1.33 \\
\hline
\end{tabular}

$\overline{l_{\mathrm{L}}}$ - experimental average length of lactyl blocks; $l_{\mathrm{CL}}{ }^{\mathrm{e}}$-experimental average length of caproyl blocks; $l_{\mathrm{G}} \mathrm{e}$ - experimental average length of glycolyl blocks; $R$-randomization ratio; $T_{\mathrm{II}}$-yield of the second mode of transesterification.

\subsection{Cyto- and Genotoxicity}

The polyesters produced in this work are intended for biomedical uses, such as drug carriers in anticancer DDSs. Despite the fact that the drug cargo has substantial cytotoxic activity, the polymeric matrices are intended to be cell and gene neutral. As a result, the four 
representatives of synthesized polyesters were evaluated for cytotoxicity and genotoxicity (Table 8).

Table 8. Results of the $u m u$-test and the NRU test in contrast to the untreated control at the highest concentrations of tested extracts $\left[1 \mathrm{mg} \mathrm{mL}^{-1}\right]$.

\begin{tabular}{cccc}
\hline \multirow{2}{*}{ Sample } & \multicolumn{2}{c}{ Genotoxicity Assay } & Cytotoxicity Assay \\
\cline { 2 - 4 } & $\boldsymbol{I R}^{\mathbf{a}} \pm \mathbf{S D}$ & $\boldsymbol{I R}^{\mathbf{b}} \pm \mathbf{S D}$ & Cells Viability \pm SD [\%] \\
\hline PLA & $0.96 \pm 0.02$ & $0.75 \pm 0.11$ & $102 \pm 2$ \\
\hline PCL & $0.94 \pm 0.11$ & $0.79 \pm 0.08$ & $100 \pm 1$ \\
\hline PLACL & $0.87 \pm 0.03$ & $0.82 \pm 0.14$ & $108 \pm 6$ \\
\hline PCLGA & $1.04 \pm 0.11$ & $0.78 \pm 0.14$ & $97 \pm 4$ \\
\hline
\end{tabular}

${ }^{\mathrm{a}}$ version without metabolic activation, ${ }^{\mathrm{b}}$ version with metabolic activation.

The NRU test was used for the cytotoxicity testing. The quantitative estimation of viable cells in tested cultures was based on their ability to accumulate the dye in their lysosomes. The viability of BALB/c 3T3 cells was not reduced below $70 \%$ as compared to the untreated control by any of the tested dilutions. As a result, all examined polymers may be declared nontoxic in the NRU assay.

The $u m u$-test was performed to assess the genotoxic potential of the produced polymeric materials. The growth of Salmonella typhimurium determining the toxicity of tested samples was evaluated by a measurement of optical density. All tested samples were not toxic for the Salmonella typhimurium (bacteria growth $>0.5$ ) with and without metabolic activation. Furthermore, the induction ratio (IR), which represents a sample's genotoxic potential, was $<1.5$ for all examined materials. This indicates that none of the produced polymers were genotoxic.

\subsection{The Possibility of Employing the Produced Polymers as Carriers of Therapeutic Drugs}

Polyesters are one of the most significant groups of biodegradable polymers. Homo-, co-, and terpolymers of L-LA, rac-LA, CL, and Gly are widely employed in medicine, e.g., as drug carriers $[3,6,39]$. The advantage of DDSs over traditional drug forms is from controlled and sustained drug release in the body, which is influenced, among other things, by the microstructure of the chain [40] and the composition of the polymer carrier [41]. Polyesters are distinguished mostly by their tunable microstructure and chemistry. As a consequence, their properties may be effectively optimized (e.g., drug release profile, degradation time, structure targeting). In our study, the synthesis conditions were optimized in terms of time, temperature, and catalyst content, which is important for biomedical applications because residuals of the catalyst may contaminate the obtained material. ${ }^{1} \mathrm{H}$ and ${ }^{13} \mathrm{C} \mathrm{NMR}$ studies confirmed the polymer structures and complete monomer conversion. Low molar mass homopolymers and atactic copolymers synthesized in the presence of $\mathrm{BiOct}_{3}$ exhibit no cytoor genotoxicity. Based on our previous experience, the obtained polyesters with a statistical microstructure can be used in the technology of short-term DDSs systems. Furthermore, a high randomization ratio of the polyester chains may be favorable owing to a more uniform drug release profile as a result of the polymer's homogeneous hydrolytic degradation.

A recent comparison of data from the synthesis of biodegradable polymers using bismuth catalysts has been published [7]. The results reported herein confirm the existing data and demonstrate the tremendous potential of $\mathrm{BiOct}_{3}$ to create random polymers. The findings are consistent with Kricheldorf's research [5,7,42], who has been investigating the utilization of $\mathrm{Bi}$ (III) compounds, such as bismuth subsalicylate and bismuth(III) n-hexanoate, in the polymerization of biodegradable polymers. Similarly, in our study the polymers were obtained with a high yield. The catalyst enabled complete monomer conversion with excellent reactivity. BiOct $_{3}$ encouraged random distribution of comonomer units along the chain, and the polymerization process produced polymers with low $Đ$. 
We are currently conducting additional research on paclitaxel-DDSs derived from these polymers. The preliminary findings of our research enable us to confirm our hypotheses. In our next article, we will present detailed results from structural, physicochemical, and biological investigations (in vitro and in vivo) of these DDSs.

\section{Conclusions}

Four various biodegradable polymeric matrices were synthesized via ROP of CL, Gly and L-LA in the presence of non-toxic PEG200-BiOct 3 catalytic system. The catalyst system characterizes high productivity by means of small amounts of the catalyst needed for the polymerization process. The structures of the resulted polyesters correspond well to theoretical assumptions. The polymers showed low polydispersity index and $M_{n}$ consistent with theoretical values. The polymers were analyzed by means of their structure and thermal properties. The results are consistent with the literature data. $\mathrm{BiOct}_{3}$ catalysts efficiently promoted homo- and copolymerization of CL, Gly, and L-LA in a variable range of monomer compositions, which were coherent with monomer feed ratios. Nevertheless, the transesterification reactions contributed to some extent to the structures with more randomized distribution of monomers along the copolymer chains.

Thermal analysis showed single glass transition temperatures indicating good homogeneity of the polymers. The amorphous nature of PLACL and low ordering of PCLGA deduced from the DSC curves are in accordance with random microstructures of the copolymers.

The results showed that $\mathrm{BiOct}_{3}$ is a well-suited catalyst, particularly for L-LA, for which preferential ring opening in relation to CL is observed during the polymerization process. The resulted polymers did not show neither cytotoxicity nor genotoxicity. Additionally, taking into account the extraordinarily low toxicity, BiOct 3 is a particularly attractive "green" catalyst for ROP of biodegradable polyesters, especially these predicted for contact with the living organisms, including drug delivery systems.

Author Contributions: I.M.D.: conceptualization, chemical, structural, analytical and pharmaceutical research, methodology, investigation, formal analysis, and writing-original draft; A.Z. (Anna Zgadzaj): biological research, methodology, investigation; A.Z. (Aldona Zalewska): DSC measurement and analysis; A.P.: GPC measurement and analysis; S.K.: GPC measurement and analysis; E.O.: investigation, formal analysis, and writing —original draft and editing; K.C.: investigation, formal analysis, and writing — original draft and editing; M.S.: conceptualization, chemical, structural, analytical and pharmaceutical research, investigation, writing - original draft, editing, and supervision. All authors have read and agreed to the published version of the manuscript.

Funding: This work was founded by the FW23/N/21:MAT Statutory Project of Medical University of Warsaw, 1 Banacha St., 02-097 Warsaw, Poland.

Institutional Review Board Statement: Not applicable.

Informed Consent Statement: Not applicable.

Data Availability Statement: The data presented in this study are available on request from the corresponding author.

Acknowledgments: The contribution of Izabela M. Domańska was realized within the Project No POWR.03.02.00-00-I009/17-00 (Operational Project Knowledge Education Development 2014-2020 co-financed by European Social Fund).

Conflicts of Interest: The authors declare that they have no known competing financial interests or personal relationships that could appear to have influenced the work described in this paper.

Sample Availability: Samples of all compounds are available from the authors. 


\section{References}

1. Orchel, A.; Jelonek, K.; Kasperczyk, J.; Dobrzynski, P.; Marcinkowski, A.; Pamula, E.; Orchel, J.; Bielecki, I.; Kulczycka, A. The Influence of Chain Microstructure of Biodegradable Copolyesters Obtained with Low-Toxic Zirconium Initiator to In Vitro Biocompatibility. BioMed Res. Int. 2013, 2013, e176946. [CrossRef] [PubMed]

2. Żółtowska, K.; Sobczak, M.; Olędzka, E. Novel Zinc-Catalytic Systems for Ring-Opening Polymerization of $\varepsilon$-Caprolactone. Molecules 2015, 20, 2816-2827. [CrossRef]

3. Żółtowska, K.; Oledzka, E.; Kuras, M.; Skrzypczak, A.; Nałęcz-Jawecki, G.; Sobczak, M. Cyto- and genotoxicity evaluation of the biomedical polyesters obtained in the presence of new zinc catalytic systems. Int. J. Polym. Mater. Polym. Biomater. 2017, 66, 768-772. [CrossRef]

4. Yang, P.B.; Davidson, M.G.; Edler, K.J.; Brown, S. Synthesis, Properties, and Applications of Bio-Based Cyclic Aliphatic Polyesters Biomacromolecules 2021, 22, 3649-3667. [CrossRef]

5. Kricheldorf, H.R.; Weidner, S.M.; Scheliga, F. Synthesis of cyclic poly(L-lactide) catalyzed by Bismuth Salicylates-A combination of two drugs. J. Polym. Sci. Part A Polym. Chem. 2019, 57, 2056-2063. [CrossRef]

6. Kasiński, A.; Zielińska-Pisklak, M.; Kowalczyk, S.; Plichta, A.; Zgadzaj, A.; Oledzka, E.; Sobczak, M. Synthesis and Characterization of New Biodegradable Injectable Thermosensitive Smart Hydrogels for 5-Fluorouracil Delivery. Int. J. Mol. Sci. 2021, 22, 8330. [CrossRef]

7. Kricheldorf, H.R. Syntheses of Biodegradable and Biocompatible Polymers by Means of Bismuth Catalysts. Chem. Rev. 2009, 109, 5579-5594. [CrossRef]

8. Huang, B.-H.; Dutta, S.; Lin, C.-C. 1.39-Main-Group Catalysts for Lactide Polymerization. In Comprehensive Inorganic Chemistry, 2nd ed.; Elsevier: Amsterdam, The Netherlands, 2013; Volume 1, pp. 1217-1249. [CrossRef]

9. Rodilla, V.; Miles, A.T.; Jenner, W.; Hawksworth, G.M. Exposure of cultured human proximal tubular cells to cadmium, mercury, zinc and bismuth: Toxicity and metallothionein induction. Chem. Biol. Interact. 1998, 115, 71-83. [CrossRef]

10. Kowalik, M.; Masternak, J.; Barszcz, B. Recent Research Trends on Bismuth Compounds in Cancer Chemoand Radiotherapy. CMC 2019, 26, 729-759. [CrossRef]

11. Kricheldorf, H.R.; Rost, S. A-B-A-Triblock and multiblock copolyesters prepared from $\varepsilon$-caprolactone, glycolide and L-lactide by means of bismuth subsalicylate. Polymer 2005, 46, 3248-3256. [CrossRef]

12. Kricheldorf, H.R.; Serra, A. Polylactones. 6. Influence of various metal salts on the optical purity of poly(L-lactide). Polym. Bull. 1985, 14, 497-502. [CrossRef]

13. Żółtowska, K.; Piotrowska, U.; Oledzka, E.; Sobczak, M. Efficient Diethylzinc/Gallic Acid and Diethylzinc/Gallic Acid Ester Catalytic Systems for the Ring-Opening Polymerization of rac-Lactide. Molecules 2015, 20, 21909-21923. [CrossRef] [PubMed]

14. Kasperczyk, J. Copolymerization of glycolide and $\varepsilon$-caprolactone, 1 . Analysis of the copolymer microstructure by means of ${ }^{1} \mathrm{H}$ and ${ }^{13}$ C NMR spectroscopy. Macromol. Chem. Phys. 1999, 200, 903-910. [CrossRef]

15. Kasperczyk, J.; Bero, M. Coordination polymerization of lactides, 2. Microstructure determination of poly[(L,L-lactide)-co- $(\varepsilon-$ caprolactone)] with ${ }^{13} \mathrm{C}$ nuclear magnetic resonance spectroscopy. Makromol. Chem. 1991, 192, 1777-1787. [CrossRef]

16. Kasperczyk, J.; Bero, M. Coordination polymerization of lactides, 4. The role of transesterification in the copolymerization of L,L-lactide and $\varepsilon$-caprolactone. Makromol. Chem. 1993, 194, 913-925. [CrossRef]

17. Bero, M.; Czapla, B.; Dobrzyński, P.; Janeczek, H.; Kasperczyk, J. Copolymerization of glycolide and $\varepsilon$-caprolactone, $2^{\mathrm{a}}$ Random copolymerization in the presence of tin octoate. Macromol. Chem. Phys. 1999, 200, 911-916. [CrossRef]

18. Dobrzynski, P. Synthesis of biodegradable copolymers with low-toxicity zirconium compounds. III. Synthesis and chainmicrostructure analysis of terpolymer obtained from L-lactide, glycolide, and $\varepsilon$-caprolactone initiated by zirconium(IV) acetylacetonate. J. Polym. Sci. A Polym. Chem. 2002, 40, 3129-3143. [CrossRef]

19. International Organization for Standardization. EN ISO 10993-5:2009 Biological Evaluation of Medical Devices-Part 5: Tests for In Vitro Cytotoxicity (ISO 10993-5:2009); Annex A Neutral Red Uptake (NRU) Cytotoxicity Test; International Organization for Standardization: Geneva, Switzerland, 2009

20. International Organization for Standardization. ISO/FDIS 13829:2000 Water Quality-Determination of the Genotoxocity of Water and Waste Water Using the Umu-Test; International Organization for Standardization: Geneva, Switzerland, 2000.

21. Sarasua, J.-R.; Prud'homme, R.E.; Wisniewski, M.; Le Borgne, A.; Spassky, N. Crystallization and Melting Behavior of Polylactides. Macromolecules 1998, 31, 3895-3905. [CrossRef]

22. Tiptipakorn, S.; Keungputpong, N.; Phothiphiphit, S.; Rimdusit, S. Effects of polycaprolactone molecular weights on thermal and mechanical properties of polybenzoxazine. J. Appl. Polym. Sci. 2015, 132, 41915. [CrossRef]

23. Magazzini, L.; Grilli, S.; Fenni, S.E.; Donetti, A.; Cavallo, D.; Monticelli, O. The Blending of Poly(glycolic acid) with Polycaprolactone and Poly(L-lactide): Promising Combinations. Polymers 2021, 13, 2780. [CrossRef]

24. Cieśla, K.; Watzeels, N.; Rahier, H. Effect of gamma irradiation on thermophysical properties of plasticized starch and starch surfactant films. Radiat. Phys. Chem. 2014, 99, 18-22. [CrossRef]

25. Rzepna, M.; Sadło, J.; Przybytniak, G.; Iuliano, A. Impact of electron beam treatment on copolymers of polylactide and poly(trimethylene carbonate) in an air atmosphere. J. Appl. Polym. Sci. 2021, 138, 50184. [CrossRef]

26. Plichta, A.; Kowalczyk, S.; Olędzka, E.; Sobczak, M.; Strawski, M. Effect of structural factors on release profiles of camptothecin from block copolymer conjugates with high load of drug. Int. J. Pharm. 2018, 538, 231-242. [CrossRef] 
27. Zhao, H.; Zhu, Y.; Sha, L. Study of the relationship between characteristics of aramid fibrids and mechanical property of aramid paper using DSC. e-Polymers 2014, 14, 139-144. [CrossRef]

28. Derakhshandeh, M.; Noroozi, N.; Schafer, L.L.; Vlassopoulos, D.; Hatzikiriakos, S.G. Dynamics of partially miscible polylactidepoly( $\varepsilon$-caprolactone) blends in the presence of cold crystallization. Rheol. Acta 2016, 55, 657-671. [CrossRef]

29. Bliley, J.M.; Marra, K.G. Chapter 11-Polymeric Biomaterials as Tissue Scaffolds. In Stem Cell Biology and Tissue Engineering in Dental Sciences; Vishwakarma, A., Sharpe, P., Shi, S., Ramalingam, M., Eds.; Academic Press: Boston, MA, USA, 2015 ; pp. 149-161. [CrossRef]

30. Fernández, J.; Etxeberria, A.; Sarasua, J.-R. Synthesis, structure and properties of poly(L-lactide-co- $\varepsilon$-caprolactone) statistical copolymers. J. Mech. Behav. Biomed. Mater. 2012, 9, 100-112. [CrossRef] [PubMed]

31. Fukushima, K.; Tabuani, D.; Abbate, C.; Arena, M.; Rizzarelli, P. Preparation, characterization and biodegradation of biopolymer nanocomposites based on fumed silica. Eur. Polym. J. 2011, 47, 139-152. [CrossRef]

32. Burg, K. Poly( $\alpha$-ester)s'. In Natural and Synthetic Biomedical Polymers; Kumbar, S.G., Laurencin, C.T., Deng, M., Eds.; Elsevier: Oxford, UK, 2014; pp. 115-121. [CrossRef]

33. D'Auria, I.; Lamberti, M.; Rescigno, R.; Venditto, V.; Mazzeo, M. Copolymerization of L-Lactide and $\varepsilon$-Caprolactone promoted by zinc complexes with phosphorus based ligands. Heliyon 2021, 7, e07630. [CrossRef]

34. Pamula, E.; Dryzek, E. Structural Changes in Surface-Modified Polymers for Medical Applications. Acta Phys. Pol. A 2008, 113, 1485-1493. [CrossRef]

35. Turek, A.; Stoklosa, K.; Borecka, A.; Paul-Samojedny, M.; Kaczmarczyk, B.; Marcinkowski, A.; Kasperczyk, J. Designing Biodegradable Wafers Based on Poly(L-lactide-co-glycolide) and Poly(glycolide-co- $\varepsilon$-caprolactone) for the Prolonged and Local Release of Idarubicin for the Therapy of Glioblastoma Multiforme. Pharm. Res. 2020, 37, 90. [CrossRef]

36. Ahmed, J.; Varshney, S.K. Polylactides-Chemistry, Properties and Green Packaging Technology: A Review. Int. J. Food Prop. 2011, 14, 37-58. [CrossRef]

37. Liu, C.B.; Gong, C.Y.; Huang, M.J.; Wang, J.W.; Pan, Y.F.; Zhang, Y.D.; Li, G.Z.; Gou, M.L.; Wang, K.; Tu, M.J.; et al. Thermoreversible gel-sol behavior of biodegradable PCL-PEG-PCL triblock copolymer in aqueous solutions. J. Biomed. Mater. Res. 2008, 84B, 165-175. [CrossRef] [PubMed]

38. Jiang, Z.; Deng, X.; Hao, J. Thermogelling hydrogels of poly( $\varepsilon$-caprolactone-co-D,L-lactide)-poly(ethylene glycol)-poly( $\varepsilon$ caprolactone-co-D,L-lactide) and poly( $\varepsilon$-caprolactone-co-L-lactide)-poly(ethylene glycol)-poly( $\varepsilon$-caprolactone-co-L-lactide) aqueous solutions. J. Polym. Sci. A Polym. Chem. 2007, 45, 4091-4099. [CrossRef]

39. Efthimiadou, E.K.; Theodosiou, M.; Toniolo, G.; Abu-Thabit, N.Y. Stimuli-responsive biopolymer nanocarriers for drug delivery applications. In Stimuli Responsive Polymeric Nanocarriers for Drug Delivery Applications; Makhlouf, A.S.H., Abu-Thabit, N.Y., Eds.; Woodhead Publishing: Sawston, UK, 2018; pp. 405-432. [CrossRef]

40. Żółtowska, K.; Piotrowska, U.; Oledzka, E.; Luchowska, U.; Sobczak, M.; Bocho-Janiszewska, A. Development of biodegradable polyesters with various microstructures for highly controlled release of epirubicin and cyclophosphamide. Eur. J. Pharm. Sci. 2017, 96, 440-448. [CrossRef]

41. Xu, Y.; Kim, C.-S.; Saylor, D.M.; Koo, D. Polymer degradation and drug delivery in PLGA-based drug-polymer applications: A review of experiments and theories. J. Biomed. Mater. Res. B Appl. Biomater. 2017, 105, 1692-1716. [CrossRef]

42. Kricheldorf, H.R.; Bornhorst, K.; Hachmann-Thiessen, H. Bismuth(III) n-Hexanoate and Tin(II) 2-Ethylhexanoate Initiated Copolymerizations of $\varepsilon$-Caprolactone and L -Lactide. Macromolecules 2005, 38, 5017-5024. [CrossRef] 